\title{
Handling conditions and microbial contamination of fish from Ouagadougou markets in Burkina Faso
}

\section{Achille S. OUEDRAOGO ${ }^{1 *}$, Adama OUEDA ${ }^{1}$, Awa GNEME ${ }^{1}$, Gueswendé L. SAVADOGO ${ }^{2}$, Nicolas BARRO ${ }^{3}$ and Gustave B. KABRE ${ }^{1}$}

\footnotetext{
${ }^{1}$ Laboratoire de Biologie et Ecologie Animales (LBEA), 03 BP 7021 Ouagadougou 03 Université de Ouagadougou, Burkina Faso.

${ }^{2}$ Institut Supérieur des Sciences de la Santé, 01 BP 1091 Bobo-Dioulasso 01, Université Polytechnique de BoboDioulasso (UPB), Burkina Faso.

${ }^{3}$ Laboratoire de Technologie Alimentaire, Centre de Recherche en Sciences Biologiques, Alimentaires et Nutritionnelles (CRSBAN), 03 B.P. 7021 Ouagadougou 03, Université de Ouagadougou, Burkina Faso.
}

Received 26 January, 2016; Accepted 17 June, 2016

\begin{abstract}
The purpose of this study was to analyze the handling conditions and microbial contamination of fish from Ouagadougou markets. In spite of the fact that fish consumption is linked to several events of alimentary infection in Burkina Faso, fewer studies were dedicated to this issue. The study was conducted using two approaches. First, an investigation conducted with fish sellers to evaluate handling hygienic conditions of fish. Secondly, microbiological analysis conducted to assess the microbiological quality of fish. Total and faecal coliforms, Staphylococcus aureus, fungic flora, Salmonella sp., Shigella sp. and Escherichia coli were the main groups found on fish specimens from Ouagadougou markets. The results showed also a predominance of women in the fish handling domain, sellers mainly illiterate, without any training in good hygienic practices (GHP). The consequences on microbiological level, was an abundance of $S$. aureus mainly on smoked fish. 57.5, 55 and $7.5 \%$ of samples have been found unsatisfactory (not good for consumption) respectively according to their contamination by $S$. aureus, faecal coliforms and fungus. Besides, Shigella sp. was found on $1 \%$ of sample, E. coli $15 \%$ and Salmonella sp. $25 \%$.
\end{abstract}

Key words: Fish, coliforms, staphylococcus, market, Ouagadougou.

\section{INTRODUCTION}

Fish is an important dietary component of people all around the world and represents a relatively cheap and accessible source of high quality protein for poorer households (Ikutegbe and Sikoki, 2014). In the world, fish consumption per habitant raised up from $10 \mathrm{~kg}$ in the $60 \mathrm{~s}$ to $19 \mathrm{~kg}$ in 2012 (FAO, 2014). In Africa, more than 200

*Corresponding author. E-mail: achillovedraogo@gmail.com. Tel: 0022676933767.

Author(s) agree that this article remain permanently open access under the terms of the Creative Commons Attribution License 4.0 International License 
million of persons consumed regularly fresh, smoked and dried fish (World Fish Center, 2005). In Burkina Faso, due to financial and economic crises (like devaluation which happened in January 1994), livestock exportation has considerably increased. This situation induced an expensiveness of meat and a shift from meat to fish consumption (Coulibaly et al., 1995). Fish is consumed fresh or transformed (smoked, fried or roasted). In urban area, fish is mainly sold fresh on markets. In rural areas, transformed fish is the most sold. In Burkina Faso, fish consumption was $1.4 \mathrm{~kg} /$ habitant in 2003 (FAO, 2009). However, due to the microbial contamination already found by some authors, the consumers are in risk. Barro et al. (2006) and Abdelrahim et al. (2012) reported some contamination of transformed fish by coliforms, Escherichia coli and some enteropathogenic bacteria, in street in Burkina Faso. In spite of this, microbiological quality of fish is not sufficiently analyzed in Burkina Faso and there is no data about handling condition and microbiological contamination of fresh fish produced and imported in Burkina Faso, this is why we sought into it. People selling fish on the street in a lack of hygiene practices could be the related factor of fish contamination. Using survey and microbiological analysis, this study aimed to highlights the bad handling conditions of fish in Ouagadougou markets and it consequence on fish contamination. Specifically, it evaluated the handling hygienic conditions of fresh, roasted, fried and smoked fish, and the microbiological quality of those fish.

\section{MATERIALS AND METHODS}

\section{Study area and handling condition survey}

The study was carried out in Ouagadougou, the capital city of Burkina Faso. Fresh, smoked, fried and roasted fish samples were collected from May to November 2013, on eleven locations throughout the city (Figure 1). Fifty one (51) fish sellers were interviewed using a set of questions, aiming to determine sellers' population characteristics (age, sex, level of instruction, level in training in Good Hygiene Practices (GHPs). Handling condition were analyzed with regard to the Sanitation Standard Operating Procedures (SSOPs): Hair protection, hands washed before selling, use of gloves and kitchen smock; the hygienic conditions of trading place (surrounding wastes, tap water availability, implement and utensil conditions).

\section{Sampling}

Sampling was done by making a purchase of fish from seller at the sales peak hours ( $7 \mathrm{am}$ to $6 \mathrm{pm}$ for fresh and smoked fish; $6 \mathrm{pm}$ to $11 \mathrm{pm}$ for fried and roasted fish). A total of 40 fish samples were collected under aseptic conditions. They were put in sterile freezer bags, kept cold to under $4^{\circ} \mathrm{C}$ with an icebox and directly transported to laboratory for microbiological analysis. Once in the laboratory, each specimen was identified according to Paugy et al. (2004), and Diouf (1991) keys. The different types of fish sampled were fresh water fish (fresh and roasted Oreochromis niloticus, fresh Saroterodon galilaeus, smocked Clarias anguilaris) and marine fish (fried Mugil cephalus and Liza sp.).

\section{Microbiological analysis}

Bacteria were isolated and counted using several culture media, with petri dishes. Depending on the type of germ, different culture media have been used. The Violet Red Bile Lactose (VRBL) was used for total and thermo tolerant coliforms and Escherichia coli isolation. Mannitol Salt Agar was used for Staphylococcus aureus, Sabouraud enriched with Chloramphenicol for toadstool (yeasts and moulds) and Salmonella/Shigella (SS) for Salmonella sp. and Shigella sp. isolation. Culture media have been sterilized at autoclave $121^{\circ} \mathrm{C}$ for $15 \mathrm{~min}$, except VRBL and SS which have been warmed to boiling point. They were cooled to about $50^{\circ} \mathrm{C}$ and poured into petri boxes (15 to $20 \mathrm{ml} / \mathrm{box}$ ) previously sterilized at $180^{\circ} \mathrm{C}$.

\section{Total viable count (TVC)}

For total and thermo tolerant coliforms NF.V08-50 and NF.V08-60 was used respectively. Ten (10) gram of different part of each fish sampled was mixed in $90 \mathrm{ml}$ of $\mathrm{NaCl} 9 \%$ water with a stomacher. Serial dilutions from $10^{-1}$ to $10^{-4}$ were prepared by diluting this mixture. $0.2 \mathrm{ml}$ of each dilution $\left(10^{-2}, 10^{-3}\right.$ and $\left.10^{-4}\right)$ was poured and spread with a sterile small rake on the agar (VRBL) in aseptic conditions. Boxes were incubated in aerobic at $37^{\circ} \mathrm{C}$ for 24 to $48 \mathrm{~h}$ for total coliforms, $44 \pm 0,5^{\circ} \mathrm{C}$ for thermo tolerant coliforms. Fungi (yeasts and moulds) were isolated and grown on Sabouraud Chloramphenicol Agar, incubated aerobically for $48 \mathrm{~h}$ at $30^{\circ} \mathrm{C}$. For $S$. aureus, NF.V08-57-2 was used. The agar (Mannitol Salt Agar) was incubated in aerobic conditions at $37^{\circ} \mathrm{C}$ for 24 to $48 \mathrm{~h}$. Presumed $S$. aureus showed shining and pigmented colonies surrounded with a yellow halo due to mannitol fermentation. Nonpathogenic Staphylococcus constituted generally red colonies which do not change agar colour. Coagulase test have been done to confirm the presence of Staphylococcus aureus.

Salmonella sp. and Shigella sp. have been isolated following normalized method (ISO 6579: 2002). $25 \mathrm{~g}$ of fish tissues have been homogenized in $225 \mathrm{ml}$ of buffered peptone water, incubated at $37^{\circ} \mathrm{C}$ for $24 \mathrm{~h}$. One milliliter of this solution was introduced in 10 $\mathrm{ml}$ of Rappaport Vasiliadis, incubated at $42^{\circ} \mathrm{C}$ for $24 \mathrm{~h}$. With a pastor pipette sterilized in alcohol then backling, few microliters were seeded in scores on SS agar, incubated at $37^{\circ} \mathrm{C}$ for $24 \mathrm{~h}$. Presumed Salmonella, Shigella and $E$. coli have been characterized with minimal gallery: Kligler Iron Agar, Simmons Citrate Agar, and Mannitol-Motility Test Medium. Pure bacteria colonies obtained from Müller Hinton agar have been seeded on those culture media, incubated at $37^{\circ} \mathrm{C}$ for 18 to $24 \mathrm{~h}$. The identification has been confirmed with API 20E gallery, which is a standard method with 20 micro tubes, aiming to realize 20 biochemical tests.

\section{Bacteria count}

Counting was done with a colony counter. The technic is based on the principle that each viable bacteria produced one colony, thus the number of colonies on the petri box corresponded to the number of living bacteria contained in the seeded solution. The number of bacteria was obtained using the formula below, where $N$ designate the numbers of bacteria, $N c$ the numbers of colonies in each petri dishes, $V_{m l}$ the volume of the inoculum, $d_{1}$ the dilution factor and $\mathrm{n} 1$ and $\mathrm{n} 2$ the numbers of dishes.

$N=\frac{\sum N c}{V_{m L \times}\left(n_{1}+0.1 n_{2}\right) \times d_{1}}$

\section{Data analysis}

The average numbers of bacteria counted on fish according to their 


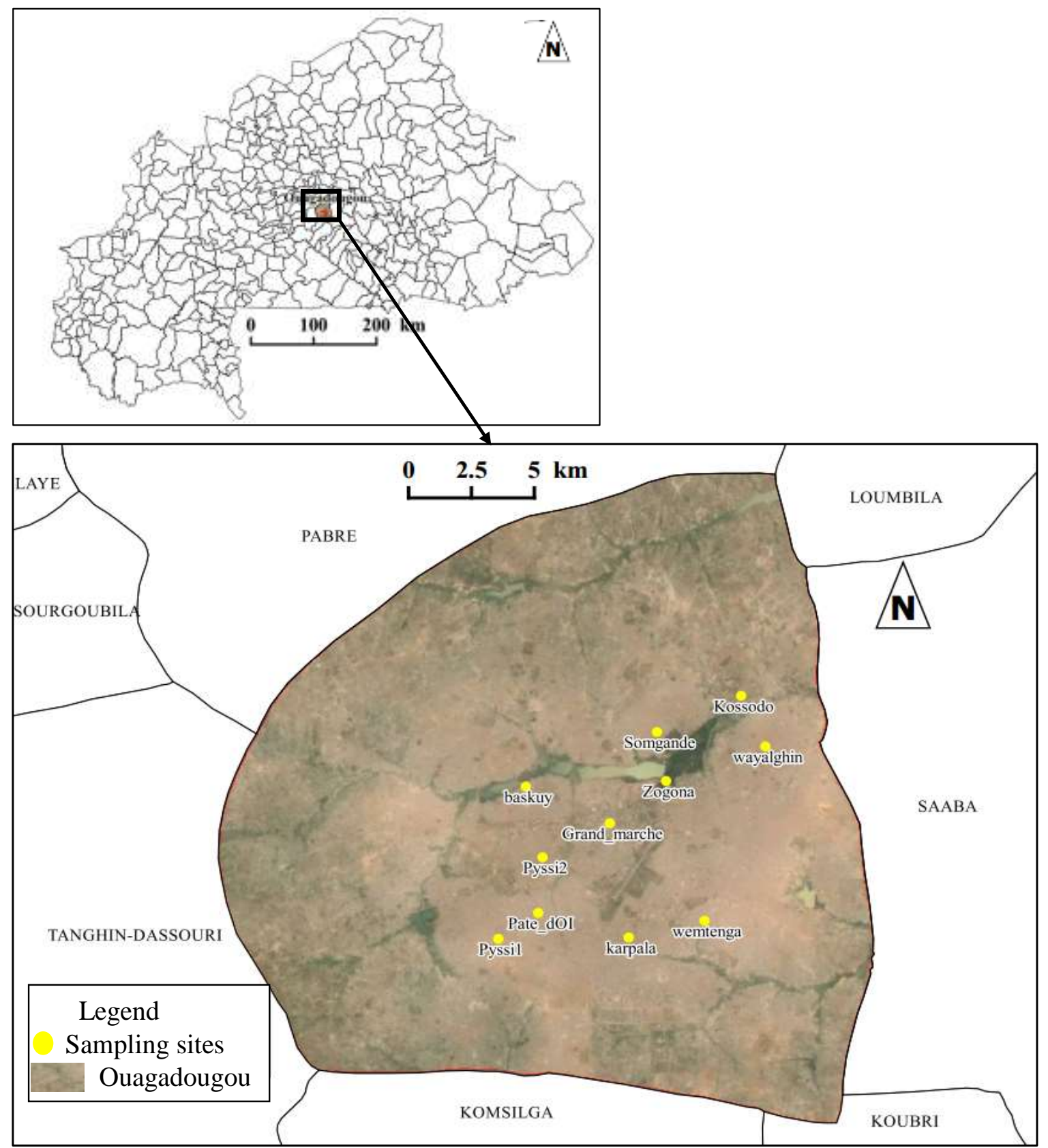

Figure 1. Sampling site in Ouagadougou town.

Table 1. Standards of the European Commission of the appreciation of raw fish and shellfish, fresh or frozen, of smocked fish ready for consumption (Regulation 2073/2005/).

\begin{tabular}{lcccl}
\hline Bacteria & Total coliform (1 g) & Faecal coliform (1 g) & S. aureus (1 g) & Salmonella/Shigella 25 g \\
\hline Level tolerated & $10^{3}$ & 10 & $10^{2}$ & Absence \\
\hline
\end{tabular}

type of cooking and the sampling sites were compared using Kruskal-Wallis and Mann-Whitney, respectively. The occurrences of phatogenic germs were assess for cooking type, sampling sites using $\mathrm{X}$-square test. Assessment of samples microbiological quality was done using European Communities' Commission standards No 2073/2005 of 15 November 2005 (Table 1) because a local regulation aiming to appreciate the food microbiologic quality was not in existence yet in Burkina Faso. Statistical analyses were 

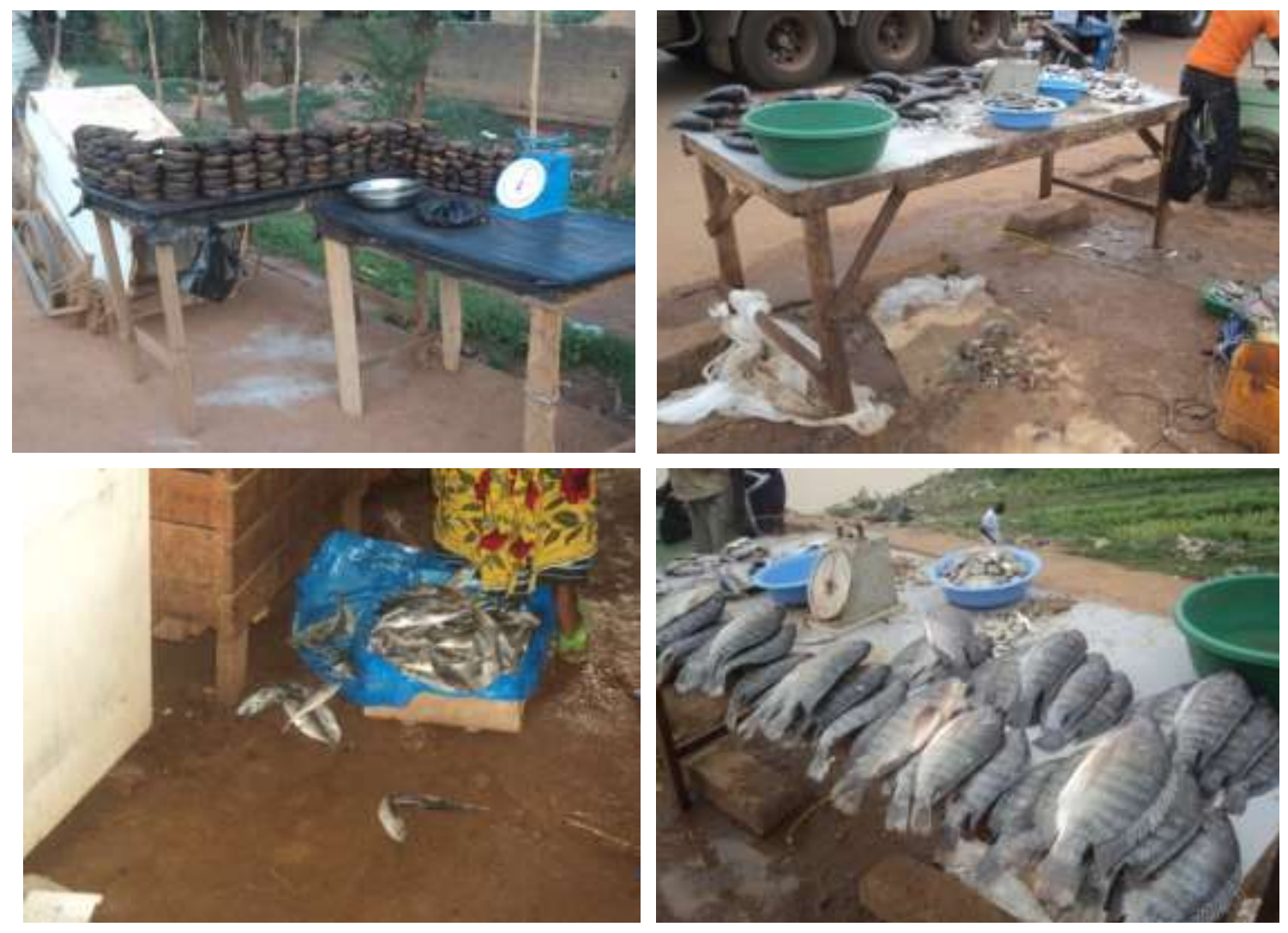

Figure 2. Photoes of four fish selling sites in Ouagadougou.

performed with $\mathrm{R}$ software version 2.15.1. The significance level was set at $p=0.05$.

\section{RESULTS}

\section{Fish handling condition}

For Sanitation Standard Operating Procedures (SSOPs) for fish handling, the study reported that more than fifty percent $(50 \%)$ of the sellers had no hair protection; over a quarter of this population do not care about hands washing. Moreover, less than twenty five percent (25\%) used protection like apron, gloves or bibs during the selling (Figure $3 a)$. Nearly seventy five percent $(75 \%)$ of sellers handled money and fish at the same time. In addition, a total of 39 selling sites prospected, more than sixty percent $(60 \%)$ did not have potable water supplied, most of them were near uncovered gutters. Insect were often present in the disposed fish that were sometime uncovered $(\sim 40 \%)$. The most used packing method was the plastic. In most case there was no waste disposal near the selling site.

For fresh fish conservation and possessing conditions selling (Figures $2 b$ and $c$ ), twelve (12) fish shop were prospected. About twenty five percent $(25 \%)$ of them were broken-down and above $20 \%$ did not have a fridge.
Most of sellers stored the wastes (liquid and solid) and threw them later in the gutter; some of sellers threw the wastes directly on the selling site. There were animals (sheep, goats, dogs, cats) on all prospected sites. The mean storage time was $24 \mathrm{~h}$ and the mean temperature for conservation (for sellers who have fridge) was $4.2^{\circ} \mathrm{C}$.

\section{Microbiological contamination}

Bacteriological analysis underlined contamination by total coliforms on $67.5 \%$ of samples, fecal coliforms on $55 \%$, S. aureus on $97.5 \%$ and fungi on $87.5 \%$. We found Salmonella sp., Escherichia coli and Shigella sp. respectively on 25,15 and $1 \%$ of fish sample. Smoked fish were the most contaminated. Fresh fish were slightly less contaminated than smoked one. Fried and roasted fish had the lower microbial load. Total and faecal coliforms, and $S$. aureus densities were different according to cooking process with the highest values being observed in smoked fish followed by fresh ones (Figure 3C). However, yeast and mold density did not show significant variation $(p=0.14)$ even if smoked fish present high density of fungi. For pathogenic germs occurrence, fresh fish had the high prevalence in Salmonella sp. $(p=0.02)$. However, the other pathogens prevalence did not show significant difference according 


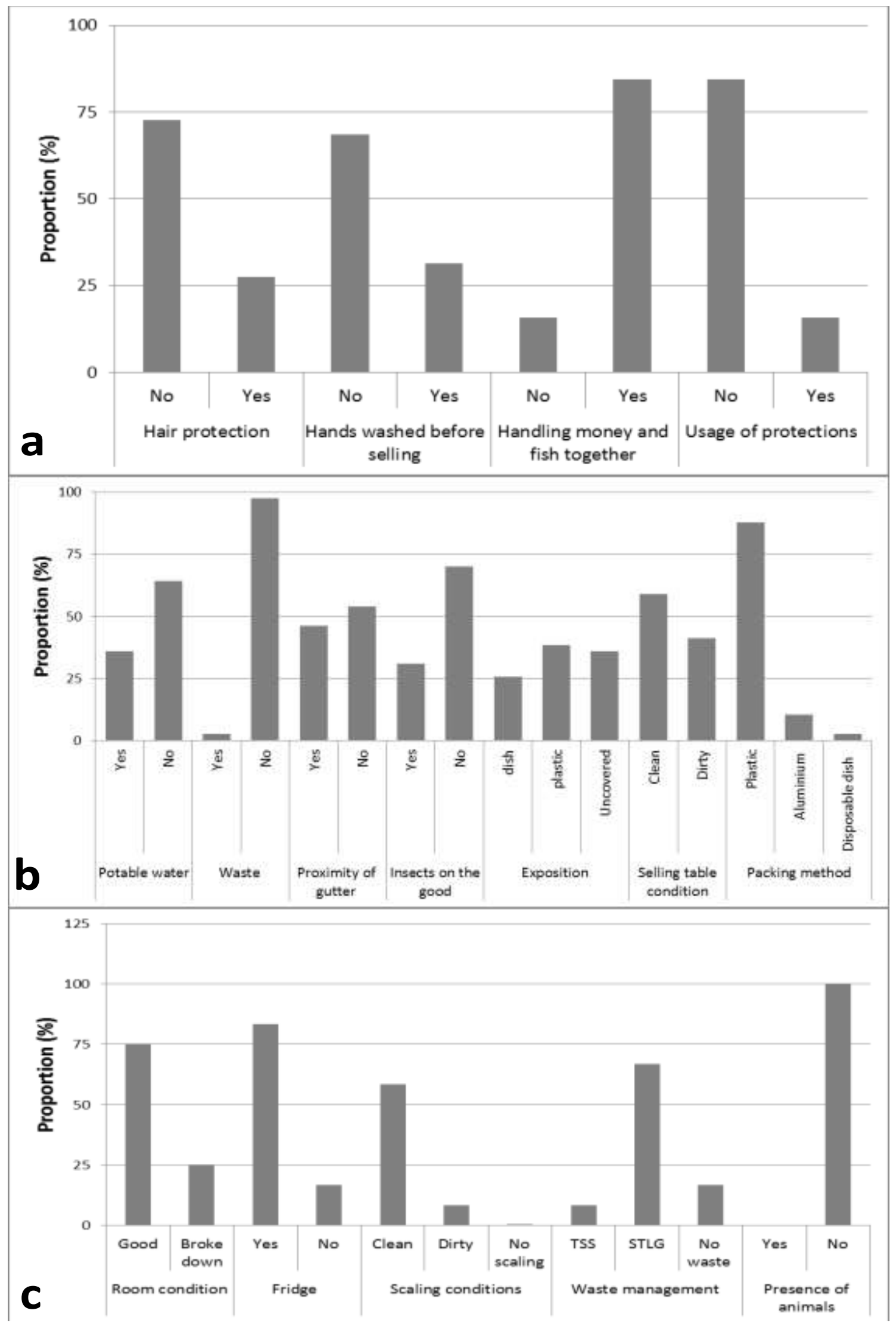

Figure 3. Characteristics of fish sellers' population (a), sellers' attitudes during the selling (b) and selling site conditions (c). 
to the cooking type.

\section{Influence of selling conditions}

According to the type of site (fixed and semi-fixed site), total coliform and $S$. aureus densities significantly vary $(p=0.005$ and $p=0.013$, respectively). However, fecal coliforms $(p=0.35)$ and fungi $(p=0.38)$ mean densities were quite the same between fixed and semi-fixed site. In regard to pathogenic germs, whereas a large predominance of salmonella $\mathrm{sp}$. on fixed site $(\mathrm{p}=0,049)$ was observed; Shigella sp. and E. coli occurrence did not depend on site (Table 1).

\section{Food safety assessment}

In line with the unhealthy handling conditions of fish underlined by this survey, the microbiological analyses showed according to the European Union Standards, that 55.0 and $57.5 \%$ of samples were unsatisfactory respectively regarding fecal coliforms and $S$. aureus. In equal, samples contaminated by Salmonella sp, Shigella sp. and E. coli (respectively 25.0, 1.0 and $15.0 \%$ ) were also unsatisfactory (Table 1). Unsatisfactory sample were those unappropriated to consumption.

\section{DISCUSSION}

Sellers do not respect strictly the good hygienic practices rules because of low instruction level and the lack of training. This have been considered like the main factor of fish contamination in this study, but also in Barro et al. (2006), Tidjani et al. (2011), and El Marnissi et al. (2012). The cooking and the selling of fish occured generally in unhealthy places. This is the same remark with Umoh and Odoba (1999), who have underlined presence of animals, insects and wastes on roasted fish selling site in Nigeria. Particularly fresh fish were processed and sold in unhealthy conditions. Consequently, the microbial loads underlined were above the acceptable levels regarding hygienic indicator germs, and varied considerably according to the cooking type. This result was confirmed not only by Ahmed et al. (2011) during their researches on the impact of smoking on fish in Cameroun, but also by Rebecca (2013) when they studied smoked fish bacteriology in Nigeria. Indeed, Abolagba and Uwagbai (2011), and Adeyeye et al. (2014) underlined a significant difference between fresh and smoked fish microbial load in Nigeria. On all the selling sites prospected, smoked fish were exposed and uncovered, in consequence, they made contact with the wind and dust germs. The high occurrence of $S$. aureus could be explained by the continuous handling of fish not only by the customers, but also by the sellers. This has been demonstrated by Sylla and Seydi (2003) when they studied the fish used in collective catering at Dakar University. The microbial load of smoked Clarias anguilaris, is less than that of Rebecca (2013). They counted $4 \times 10^{5} \mathrm{UFC} / \mathrm{g}$ and showed that this number varied according to the type of site and season. Fresh fish presented a contamination level lower than smoked one. Abolagba and Uwagbai (2011), underlined that microorganisms isolated from fresh fish could be considered like normal flora. These germs are generally nonpathogenic and can produce bacteriocins against other invader bacteria. One hundred percent $(100 \%)$ of fresh Sarotherondon galilaeus were contaminated by Salmonella sp. because of a primordial contamination in their living environment (river's water). Indeed, bad handling conditions during the selling (dirty and uncovered table, non-hygienic defrosting and evisceration process) could also explain this high occurrence. This is the same remarks by Akaki et al. (2012) when they studied roasted fish bacteriology in Yamoussocro (Côte d'Ivoire). Frying and roasting destroy efficiently microorganisms of fish (Oladipo and Bankole, 2013). Theoretically, fried and roasted fish do not have much microbial load. Actually, this is impossible because they are submitted to many handlings, multiplying risks of contamination from sellers, like Barro et al. (2006) showed in their study on the hygienic conditions of processing and selling sites of street food in Ouagadougou.

\section{Conclusion}

In Burkina Faso, particularly in Ouagadougou, due to meat expensiveness, fish have been progressively the main important source of animal proteins. Then, since 1994, his consumption is becoming more and more important. Fish is consumed generally after several cooking methods: Smoking, roasting, frying. Unfortunately, majority of consumers have no information about microbiological quality of fish consumed. In consideration of results obtained in this study, we aim to evaluate the nutritional value of fish just after the capture and just before the consumption in order to underline the effect of conservation and transformation proceedings. This different analysis will produce results usable in population sensitization about dangers linked to fish consumption.

\section{CONFLICT OF INTERESTS}

The authors have not declared any conflict of interests.

\section{ACKNOWLEDGMENTS}

The authors thank SUSFISH project (Sustainable 
Management of Water and Fish Resources in Burkina Faso) for financial support during this study. They thanks also $\mathrm{Dr}$ Magloire Boungou, $\mathrm{Dr}$ Malika Kangoyé, Laboratoire de Biologie et Ecologie Animales, Université de Ouagadougou, Burkina Faso, Serge Bagré, Salomon Bouda, Laboratoire de Technologie Alimentaire, Université de Ouagadougou, Burkina Faso, for support and frank collaboration during this work. They also thank Rosalie Ilboudo for correcting this paper and fish sellers for responding to our questionnaire.

\section{REFERENCES}

Abdelrahim AM, Tidjani A, Doutoum AA, Barro N, Traore AS (2012). Evaluation de la qualité microbiologique des poissons braisés et de leurs assaisonnements vendus dans les rues de la ville de Ouagadougou (Burkina Faso). Revue de Microbiologie et Hygiène Alimentaire 23(69):47-54.

Abolagba OJ, Uwagbai EC (2011). A comparative analysis of the microbial load of smoke-dried fishes (Ethmalosa fimbriata and Pseudotolithus elongatus) sold in Oba and Koko markets in Edo and Delta States, Nigeria at different seasons. Australian Journal of Basic and Applied Sciences 5(5):544-550.

Adeyeye S, Oyewole OB, Obadina AO, Omemu AM (2015). Microbiological assessment of traditional smoked silver catfish (Chrysichtys nigrodigitatus). African Journal of Microbiology Research 9(2):111-116.

Ahmed A, Dodo A, Bouba AM, Clement S, Dzudie T (2011). Influence of Traditional Drying and Smoke-Drying on the Quality of Three Fish Species (Tilapia nilotica, Silurus glanis and Arius parkii) from Lagdo Lake, Cameroon. Journal of Animal and Veterinary Advances 10(3):301-306.

Akaki K D, Sadat AW, Coulibaly K (2012). Bacteriological Study of Grilled Fish Consumed in Yamoussoukro Commune, Political Capital of Côte d'Ivoire. Current Research Journal of Biological Sciences 4(3):297-300.

Barro N, Bello A, Savadogo A, Ouattara CA, Ilboudo AJ, Traoré A (2006). Hygienic status assessment of dish washing waters, utensils, hands and pieces of money from street food processing sites in Ouagadougou (Burkina Faso). African Journal of Biotechnology 5(11):1107-1112

Coulibaly ND, Salembéré S, Bessin R (1995). La clinostomose larvaire des poissons Cichlidés du lac de la kompienga au Burkina Faso : des menaces pour l'exploitation halieutique et la santé publique. Cahier Santé 5:189-193.
Diouf PS (1991). Guide de détermination rapide des mulets des estuaires sénégalais. Centre de recherche océanographique de Dakar-Tiaroye, $129 p$

El Marnissi B, Bennani L, Oulali A, Abouch M, Belkhou R (2012). Contribution à l'étude de la qualité microbiologique de denrées alimentaires commercialisées à fes-boulemane. Revue de Microbiologie Industrielle, Sanitaire, et Environnementale 6(1):98117.

FAO (2009). Directives pour l'inspection du poisson fondée sur les risques. Etude FAO alimentation et nutrition, No. 90, ISBN 978-92-5206131-1.

FAO (2014). La situation mondiale des pêches et de l'aquaculture 2014. ISBN: 978-92-5-208275-0.

Ikutegbe V, Sikoki $F$ (2014). Microbiological and biochemical spoilage of smoked-dried fish sold in West African open markets. Food Chemistry 161:332-336.

Oladipo I, Bankole S (2013). Nutritional and microbial quality of fresh and dried Clarias gariepinus and Oreochromis niloticus. International Journal of Applied Microbiology and Biotechnology Research 1:1-6

Paugy D, Lévèque $C$, Teugels GG (2004). Poissons d'eaux douces et saumâtres de l'Afrique de l'Ouest, Edition complète. Edition IRD, MNHN, MRAC, $816 \mathrm{p}$

Rebecca E (2013). Microflora of fresh and smoke-dried fish in Yenagoa metropolis, Nigeria. African Journal of Microbiology Research 7(35):4451-4456.

Sylla K, Seydi M, (2003). Etude de la qualité hygiénique du poisson utilisé en restauration collective universitaire à Dakar (Sénégal). Revue Africaine de Santé et de Productions Animales E.I.S.M.V. de Dakar.

Tidjani A, Djikpo T, Diguimbaye M, Rangamarde CD (2011). Evaluation de la qualité microbiologique du poisson frais dans la région du Mayo-Kebbi au Tchad. Ann. Univ. N'Djamena. Sér. C N ${ }^{\circ} 5$, Sci. Exactes Appl. pp. 152-166.

Umoh VJ, Odoba MB (1999). Safety and quality evaluation of street foods sold in Zaria. Nigeria. Food Control 10:9-14.

World Fish Center (2005). Le poisson et la sécurité alimentaire en Afrique. World Fish Center, Penang (Malaisie). 11p. 